\title{
Extraction Socket Preservation with or without Membranes, Soft Tissue Influence on Post Extraction Alveolar Ridge Preservation: a Systematic Review
}

\author{
Ricardo Faria-Almeida $^{1}$, Inesa Astramskaite-Januseviciene ${ }^{2}$, Algirdas Puisys ${ }^{3}$, Francisco Correia ${ }^{1}$ \\ ${ }^{1}$ Department of Oral Surgery and Oral Medicine, Porto University of Dental Medicine, Portugal. \\ ${ }^{2}$ Department of Oral and Maxillofacial Surgery, Faculty of Odontology, Medical Academy, Lithuanian University of Health \\ Sciences, Kaunas, Lithuania. \\ ${ }^{3} \mathrm{VIC}$ clinic, private practice, Vilnius, Lithuania.
}

\author{
Corresponding Author: \\ Ricardo Faria-Almeida \\ Department of Oral Surgery and Oral Medicine \\ Porto University of Dental Medicine \\ Rua Dr. Manuel Pereira da Silva, 4200-393 Porto \\ Portugal \\ Phone: +351937230675 \\ Fax: +3515193259 \\ E-mail: rfaperio@gmail.com
}

\begin{abstract}
Objectives: The purpose of this systematic review was to assess quantitatively and qualitatively the influence of two different factors: membranes and soft tissue graft influence for the extraction socket preservation.

Material and Methods: A wide-ranging electronic search was performed in six databases up to 30 of November 2018 in order to identify all the clinical and randomized clinical trials performed in humans published with no data restriction. The inclusion criteria were extraction socket preservation with and without membranes or a soft tissue graft in a intact socket with at least six months of follow-up, have more than 12 patients or treat more than 12 sites per group and evaluated at least one of the primary outcomes measures (radiographic measures histological assessment, clinical measures).

Results: From an initial search of 1524 studies only 6 papers fulfil the inclusion and exclusion criterions. All the six selected papers, presented a wide heterogeneity of treatments used, evaluated variables and observation period that made impossible to recommend any specific techniques and/or material to achieve better results. The limited data found suggest that the used of membrane reveals to achieve better results. It wasn't possible to observe in any clinical trial that compares the used of soft tissue graft.

Conclusions: New trials need to be performed in order to identify what specific techniques and/or materials are better to decrease the reabsorption of the socket after tooth extraction. Clinical trials designed to understand when/how the soft tissues grafts influence at the socket preservation is needed.
\end{abstract}

Keywords: alveolar bone loss; bone remodeling; tooth socket; systematic review.

Accepted for publication: 5 September 2019

To cite this article:

Faria-Almeida R, Astramskaite-Januseviciene I, Puisys A, Correia F.

Extraction Socket Preservation with or without Membranes, Soft Tissue Influence on Post Extraction Alveolar Ridge Preservation: a Systematic Review

J Oral Maxillofac Res 2019;10(3):e5

URL: http://www.ejomr.org/JOMR/archives/2019/3/e5/v10n3e5.pdf

doi: $10.5037 /$ jomr.2019.10305 


\section{INTRODUCTION}

One of the goals of the periodontal treatment is to maintain the teeth in good conditions to provide health, function and aesthetics to the patients [1]. However, sometimes as a result of caries, periodontal disease, endodontic lesions and others, tooth extraction is inevitable.

There are several options to give to the patients as an alternative to replace the extracted teeth, from removal to fixed dental prosthesis, from implant to adhesive fixed prosthesis, each of them with good results in terms of survival rates with long term follow-ups according to the literature, when well indicated $[\underline{2}, \underline{3}]$. It is clear that all of these options give to the patients an alternative to the teeth lost, but they don't solve the biological and dimensional changes that occur after tooth extraction.

Tooth extraction begins a sequence of biological changes, with intense resorption of the alveolar bone, invagination of the mucosa, just in the first weeks after [4-8]. The quantity and extent of bone process changes are dependent on several factors, which in all of the situations leads to alveolar ridge resorption, in the three-dimensional space $[9, \underline{10}]$.

In the last years, the goal was not only to solve the existing problem but mainly to avoid the problem or at least to reduce the amount of hard and soft tissue reabsorption over the time. Several different techniques and approaches offer clinicians different possibilities to reach this goal.

From the alveolar ridge preservation $[11,12]$, to immediate implants [13-15] and also to the socket shield technique to immediate implant placement [1618] the clinician have now several different options with a different type of indications as well as different level of scientific background.

A wide variety of alveolar ridge preservation treatment modalities have been described in the last 20 years, including socket grafting with a biomaterial alone [19], overbuilding of the facial bone wall [20], occluding the access to the socket by interposing a barrier element [12], or a combination of some of them [21], with or without using soft tissue grafts to allow primary intention healing.

There are already in the literature several systematics reviews [22-26] that were designed to give the clinicians the state of art of these techniques to allow them to make the best clinical decision. However, there is limited information based on randomized clinical trials or clinical trials to address the real advantages of alveolar ridge preservation techniques.
Unfortunately, is not clear yet, which technique and materials are the most suitable for socket preservation: autogenous [27], allogenic [19, 28] or alloplastic [29]. Furthermore, is still unclear the need of a bone graft, a membrane or only soft tissue graft, as well as the influence of soft tissue impact to socket preservation. Therefore, preservation of alveolar ridge may lead to less reabsorption, but the quantity of regenerated bone, as well as the density, might be variable [30].

Hence, a systematic review of the current literature was conducted in order to analyse the outcome of socket preservation with and without membrane and determine the influence of soft tissues for ridge preservation.

\section{MATERIAL AND METHODS}

This systematic review attempted to assess quantitatively and qualitatively the influence of two different factors i.e. membranes and soft tissue graft influence, for the extraction socket preservation.

\section{Protocol and registration}

The review was registered in an international prospective register for systematic reviews "PROSPERO".

This systematic review was performed according to the guidance of the Cochrane hand book [31] and the writing obeyed to the PRISMA Statement (Preferred Reporting Items for Systematic Review and MetaAnalysis) [32].

\section{Focus question}

The research questions of this systematic review were "Are there radiological, histological, histomorphometric or clinical differences in humans extraction socket preservation when we are performed with and without membranes with a follow-up of at least 6 months?" and "Are there radiological, histological, histomorphometric or clinical differences in humans extraction socket preservation when a soft tissue graft is performed with a follow-up of at least 6 months?"

The focus questions development according to the PICOST criterions for this systematic review is described in Table 1 and 2.

\section{Information sources}

A wide-ranging electronic search for all related articles up to 30 of November 2018 was performed 
Table 1. Focus question 1 development according to the PICOST

\begin{tabular}{l|l}
\hline \multicolumn{1}{c|}{ Component } & \multicolumn{1}{|c}{ Description } \\
\hline Population (P) & Humans \\
\hline Intervention (I) & Extraction socket \\
\hline Comparison (C) & With or without membranes \\
\hline Outcome (O) & $\begin{array}{l}\text { Radiological, histological, histomorphometric or } \\
\text { clinical }\end{array}$ \\
\hline Study design (S) & Clinical trial; randomized controlled trial \\
\hline Time (T) & 6 months there radiological, histological, \\
\hline Focus question & $\begin{array}{l}\text { "Are there istomorphometric or clinical differences in } \\
\text { humans extraction socket preservation when we } \\
\text { are performed with and without membranes with } \\
\text { a follow-up of at least 6 months?" }\end{array}$ \\
\hline
\end{tabular}

using the following electronic databases: LILACS; PubMed; SciELO; ScienceDirect; Scopus; Web of Science $^{\mathrm{TM}}$.

\section{Search}

Electronic searches for clinical trials and randomized clinical trials published with no data restriction and written in English, Portuguese, Spanish, Italian, German, Lithuanian or French that presented at least one of the keyword combinations: "socket preservation", "ridge preservation" was performed. In PubMed a MeSH terms explore was performed too "((“Tooth Socket" $[\mathrm{MeSH}])$ AND "Preservation, Biological"[Mesh]) OR "Alveolar Ridge Augmentation" $[\mathrm{MeSH}])$ )".

An additional manual search among periodical journals and the grey literature of relevant papers was also performed.

\section{Selection of studies}

The paper selection based on titles, abstracts and full text was performed by CF and FAR.

In all of this steps attention was payed for the inclusion/exclusion characteristics in order to locate all the paper included in this systematic review.

Disagreements were solved by reviewers discussion prior to final inclusion or exclusion. Kappa test of the agreement was performed and confirmed the high agreement between researches.

\section{Types of publications}

This systematic review included only human clinical trials or randomized clinical trials. Letters, editorials, $\mathrm{PhD}$ theses, and abstracts were excluded.
Table 2. Focus question 2 development according to the PICOST

\begin{tabular}{l|l}
\hline \multicolumn{1}{c|}{ Component } & \multicolumn{1}{|c}{ Description } \\
\hline Population (P) & Humans \\
\hline Intervention (I) & Extraction socket \\
\hline Comparison (C) & Soft tissue graft \\
\hline Outcome (O) & $\begin{array}{l}\text { Radiological, histological, histomorphometric or } \\
\text { clinical }\end{array}$ \\
\hline Study design (S) & Clinical trial; randomized controlled trial \\
\hline Time (T) & 6 months there radiological, histological, \\
\hline Focus question & $\begin{array}{l}\text { “Are there } \\
\text { histomorphometric or clinical differences in } \\
\text { humans extraction socket preservation when a } \\
\text { soft tissue graft is performed with a follow-up of } \\
\text { at least 6 months?” }\end{array}$ \\
\hline
\end{tabular}

\section{Types of studies}

This systematic review included clinical trials or randomized clinical trials performed in human with at least of six months of follow-up, with more than 12 patients or treat more than 12 sites per group.

\section{Types of participants/population}

Human patients that had been performed an extraction socket preservation with or without membranes or a soft tissue graft in an intact socket.

\section{Inclusion and exclusion criteria}

The studies selection were based on the following inclusion and exclusion criteria:

Inclusion criteria:

- Humans;

- Clinical trial or randomized clinical trial;

- Minimum of 12 patients or 12 sites per group;

- Group with and without membrane;

- Use of membrane or soft tissue graft;

- Report of at least one primary outcome.

Exclusion criteria:

- Animal studies;

- Sockets that weren't intact.

\section{Sequential search strategy}

The duplicated titles were excluded prior to the two investigators (CF and FAR) carefully screened all studies based on titles and abstracts considering the inclusion and exclusion criteria.

For the study eligibility, the full texts were accessed and confirmed that they have the characteristics to be included in this systematic review. The authors of the papers were contacted when data was missing or to clarify ambiguous reports. 


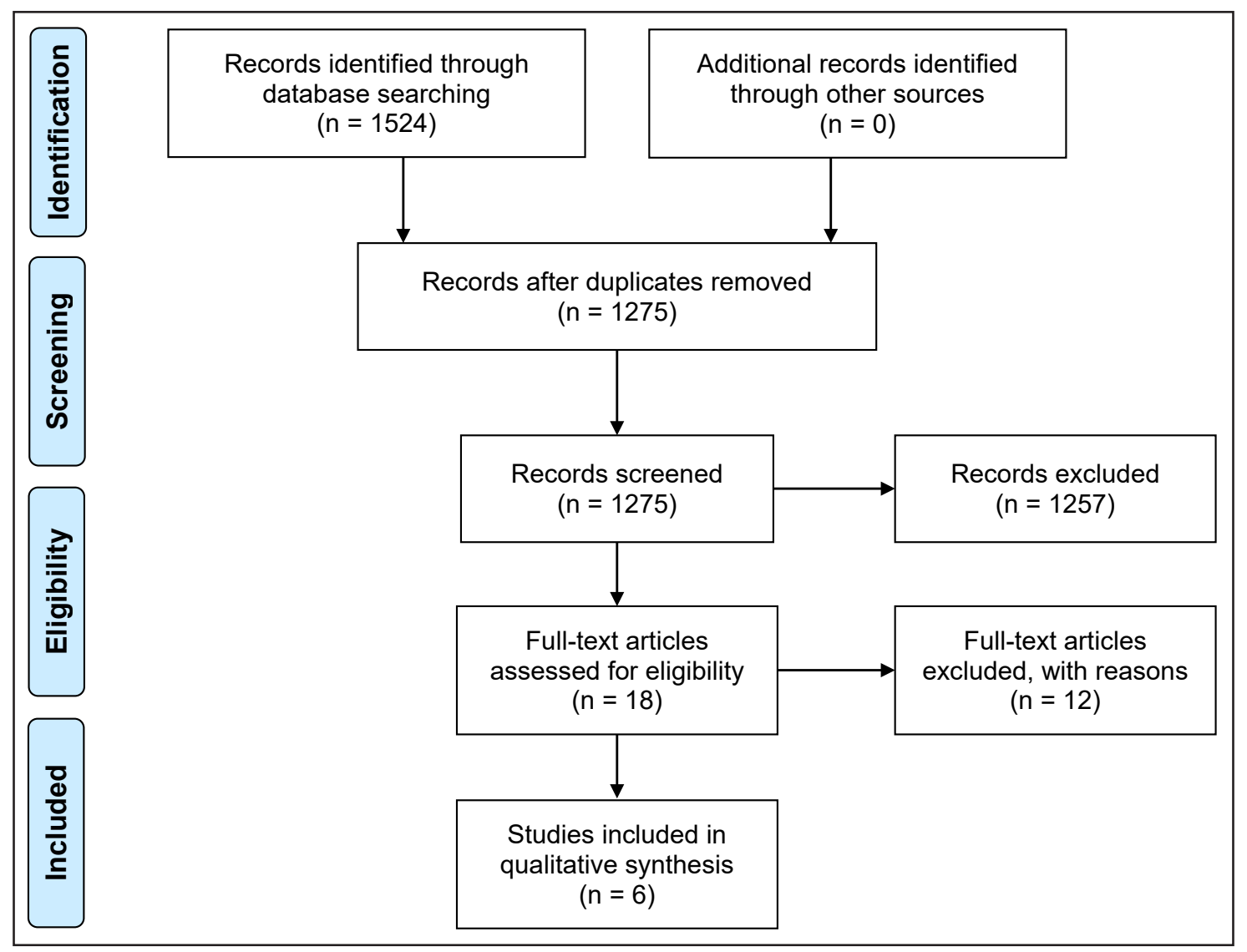

Figure 1. Literature search and procedure for the choice of the papers.

The flow chart representing the literature search is shown in Figure 1.

\section{Data extraction}

After the selection of the papers to be included data regarding the methods, participants, intervention, outcomes and the risk of bias were extracted.

\section{Data items}

Primary outcome measures:

- Radiographic measures: clinical trials that radiographically evaluated the ridge dimensions previous to the socket preservation and at follow-up.

- Histological/histomorphometric assessment: clinical trials that assess bone quantity and/or quality and/or residual graft material at follow-up.

- Clinical measures: clinical trials that in a clinical way evaluating the ridge dimensions and $\backslash$ or gingival recession andlor keratinized tissue width previous to the socket preservation and at follow-up.

Secondary outcome measures:

- Clinical outcome: clinical findings reported using any biomaterial.
- Clinical complications: e.g. membrane exposure, graft failure, infections.

\section{Risk of bias within studies}

The present systematic review was written in accordance with the PRISMA statement guidelines of transparent reporting for systematic review and meta-analyses [32]. The risk of bias assessment was carried out based on the guidance of the Cochrane handbook [31] for systematic review interventions.

The risk of bias was ranked on a three-level scale:

1. Low risk of bias: possible risk of bias which is unlikely to alter report outcomes.

2. Moderated risk of bias: possible risk of bias which may alter report outcomes.

3. High risk of bias: possible risk of bias which seriously weakens the confidence in reported outcomes.

\section{Statistical analysis}

Based on the large variation types of the intervention included, as well as the studies design, a meta-analysis was not possible to be performed. 


\section{RESULTS}

\section{Study selection}

The initial search identified a total of 1524 articles, 249 were excluded subsequently because of being duplicate. Following the screening of article titles, 242 potentially relevant articles where identified for abstract reading were the inclusion and exclusion criteria were applied. Independent screening of abstracts resulted in 18 possibly included articles. After read and analysed the 18 full-text articles a total of six articles met the inclusion criteria and were selected for this systematic review.

The $\kappa$ values for the inter-reviewer agreement of the two researchers (FC and FAR) for potentially relevant articles were $>0.9$ (titles and abstracts) and $>0.9$ (full-text articles), indicating an "almost perfect agreement" between the 2 reviewers.

Figure 1 displays the search strategy and the screening process leading to the selection of the included six trials.

\section{Exclusion of studies}

The most frequent reasons for excluding the twelve studies after full-text assessment was as follows:

1. Report guided bone regeneration and not socket preservation [33-36].

2. The number of sites per group, less than 12 [3739].

3. Follow-up, less than 6 months [40-42].

4. Type of study wasn't a clinical trials or randomized clinical trials [43].

5. Doesn't report information about the use of a membrane or a soft tissue graft against a control group [44].

\section{Quality assessment}

The quality assessment (Table 3 ) revealed that two articles met a low risk of bias $[45,46]$ and four $[\underline{12}, \underline{21}, \underline{47}, \underline{48}]$ met a high risk of bias.

\section{Types of studies}

Three $[\underline{21}, \underline{45}, \underline{48}]$ were randomized control trials, one [12] was split-mouth randomized control trial and two $[46,47]$ were designed as a clinical trial.

The studies that compose this systematic review were conducted in seven different countries: two at USA $[\underline{21}, \underline{46}]$ and at Italy $[\underline{45}, \underline{48}]$; one at Serbia [12] and Korea [47].

Only one of the included papers of Nam at al. [47] report received funding source from a Ministry of Knowledge and Economy of Seoul, Korea and National Research Foundation of Seoul, Korea.

The studies research were performed at Universities in four of the trials $[\underline{12}, \underline{46-48}]$, one of the trials [45] was performed in two private practices private centres and one [21] doesn't report where it was performed.

\section{Characteristics of outcome measures}

The included papers present a wide heterogeneity of treatments used, evaluated variables and observation period.

Related to the clinical variables used, three trials evaluated the dimensional changes based on cone-beam computed tomography (CBCT) analysis $[21,45,48]$ (Table 4), one trial based on periapical X-ray [47] (Table 5); one trial based in clinical variables [12] (Table 6); and four trials gives some information about the histological/ histomorphometric analysis [21, $\underline{46-48]}$ (Table 7).

\section{Cone-beam computed tomography analysis}

Table 4 shows the selected papers $[\underline{21}, \underline{45}, \underline{48}]$ that present results based on the $\mathrm{CBCT}$ analysis.

Table 3. Risk of bias at the selected studies

\begin{tabular}{l|c|c|c|c|c|c}
\hline \multicolumn{1}{c|}{ Study } & $\begin{array}{c}\text { Year of } \\
\text { publication }\end{array}$ & $\begin{array}{c}\text { Adequate } \\
\text { sequence } \\
\text { generation? }\end{array}$ & $\begin{array}{c}\text { Allocation } \\
\text { concealment? }\end{array}$ & $\begin{array}{c}\text { Blinding? } \\
\text { All outcomes }\end{array}$ & $\begin{array}{c}\text { Incomplete } \\
\text { outcome data } \\
\text { addressd? }\end{array}$ & $\begin{array}{c}\text { Risk of } \\
\text { bias }\end{array}$ \\
\hline Lekovic et al. [12] & 1998 & Low & Low & Low & Low & Low \\
\hline Iasella et al. [21] & 2003 & High & Low & Unclear & Unclear & High \\
\hline Meloni et al. [45] & 2015 & Low & Low & Low & Unclear & Low \\
\hline Perelman-Karmon et al. [46] & 2012 & Low & Low & Unclear & Unclear & Low \\
\hline Nam et al. [47] & 2010 & Unclear & Unclear & Unclear & High & High \\
\hline Barone et al. [48] & 2008 & High & Low & Low & Unclear & High \\
\hline
\end{tabular}

Low $=$ low risk of bias; Unclear $=$ unclear risk of bias; High $=$ high risk of bias. 
Table 4. Study's that reported cone-beam computed tomography analysis

\begin{tabular}{|c|c|c|c|c|c|}
\hline Study & $\begin{array}{c}\text { Extraction } \\
\text { location }\end{array}$ & Preservation method & $\begin{array}{c}\text { Difference } \\
\text { (initial vs follow-up) }\end{array}$ & $\begin{array}{l}\text { Control } \\
\text { group }\end{array}$ & $\begin{array}{c}\text { Period } \\
\text { observation }\end{array}$ \\
\hline \multirow[b]{2}{*}{ Iasella et al. [21] } & \multirow[b]{2}{*}{$\begin{array}{c}1,2,3,4 \\
5,6\end{array}$} & Group A - EXT & \multirow{2}{*}{$\begin{array}{c}\text { Alveolar ridge width: } \\
\text { Group A: } \\
17.28 \text { (SD 1.2)/15.68 (SD 1.13) } \\
\text { vs } \\
\text { Group B: } \\
16.91(\mathrm{SD} 1.34) / 15.44 \text { (SD 1.33) }\end{array}$} & \multirow[b]{2}{*}{$\begin{array}{l}12 \text { patients, } \\
12 \text { sockets }\end{array}$} & \multirow[b]{2}{*}{6 months } \\
\hline & & $\begin{array}{c}\text { Group B: RP with a mineralized } \\
\text { freeze-dried bone allograft, } 500 \text { to } \\
1,000 \mu \mathrm{m} \text { particle size, and a collagen } \\
\text { membrane }\end{array}$ & & & \\
\hline \multirow[t]{2}{*}{ Meloni et al. [45] } & \multirow[t]{2}{*}{$\begin{array}{c}\text { Not } \\
\text { specified }\end{array}$} & $\begin{array}{c}\text { Socket grafting with deproteinized } \\
\text { bovine bone and sealed with epithelial } \\
\text { connective tissue graft or porcine } \\
\text { collagen matrix }\end{array}$ & $\begin{array}{c}\text { Horizontal bone volume } \\
\text { (with collagen vs control): } \\
\text { Level A } \\
\text { ( } 1 \mathrm{~mm} \text { below the most coronal aspect of } \\
\text { the bone crest): } \\
8.24 / 7.7 \text { vs } 8.39 / 7.72 . \\
\text { Level B } \\
\text { ( } 3 \mathrm{~mm} \text { below the most coronal aspect of } \\
\text { the bone crest) } \\
8.18 / 7.35 \mathrm{vs} 8.53 / 7.62 . \\
\text { Level C } \\
(5 \mathrm{~mm} \text { below the most coronal aspect of } \\
\text { the bone crest) } \\
8.21 / 7.99 \text { vs } 8.27 / 7.96\end{array}$ & \multirow[t]{2}{*}{$\begin{array}{c}15 \text { patients, } \\
15 \text { sockets }\end{array}$} & \multirow[t]{2}{*}{17 months } \\
\hline & & & $\begin{array}{c}\text { Vertical bone volume } \\
\text { (with collagen vs control): } \\
\text { Level D } \\
17.28 / 16.58 \text { vs } 16.91 / 15.44\end{array}$ & & \\
\hline \multirow[b]{2}{*}{ Barone et al. [48] } & \multirow[b]{2}{*}{$\begin{array}{c}\text { Not } \\
\text { specified }\end{array}$} & Group A - EXT & Group RP: & \multirow[b]{2}{*}{$\begin{array}{l}20 \text { patients, } \\
20 \text { sockets }\end{array}$} & \multirow[b]{2}{*}{$\begin{array}{c}7 \text { to } 9 \\
\text { months }\end{array}$} \\
\hline & & $\begin{array}{l}\text { Group B: preservation procedure with } \\
\text { corticocancellous porcine bone } \\
\text { (MP3, Osteobiol }^{\mathbb{}} \text { ) and collagen } \\
\text { membrane }\left(\text { Evolution, Osteobiol }^{\mathbb{Q}}\right)\end{array}$ & $\begin{array}{c}10.6(\mathrm{SD} 1) / 8.1(\mathrm{SD} 1.4) \\
\text { vs } \\
\text { Group EXT: } \\
10.8(\mathrm{SD} 0.8) / 6.3(\mathrm{SD} 0.8)\end{array}$ & & \\
\hline
\end{tabular}

$\mathrm{EXT}=$ extraction alone; $\mathrm{RP}=$ ridge preservation.

Table 5. Study's that reported periapical X-ray analysis

\begin{tabular}{|c|c|c|c|c|c|}
\hline References & $\begin{array}{l}\text { Extraction } \\
\text { location }\end{array}$ & Preservation method & $\begin{array}{c}\text { Difference } \\
\text { (initial vs follow-up) }\end{array}$ & $\begin{array}{l}\text { Control } \\
\text { group }\end{array}$ & $\begin{array}{c}\text { Period } \\
\text { observation }\end{array}$ \\
\hline \multirow{3}{*}{ Nam et al. [47] } & \multirow{3}{*}{ Various } & \multirow{3}{*}{$\begin{array}{c}\text { Group A - bovine bone mineral: } \\
\text { OSC-B (Nano - Intelligent Bioengineering, Seoul, Korea) } \\
\text { vs } \\
\text { Synthetic oligopeptide - Ossegen-X15 (Nano Intelligent) } \\
\text { vs } \\
\text { collagen membrane - Bio-Gide }{ }^{\circledR}\end{array}$} & $\begin{array}{c}\text { Vertical buccal: } \\
15.8 / 16 \text { vs } 12.7 / 11.8\end{array}$ & \multirow{3}{*}{$42 / 15$} & \multirow{3}{*}{$6-8$ months } \\
\hline & & & $\begin{array}{l}\text { Vertical lingual: } \\
13.9 / 13.8 \text { vs } 11.8 / 12.7\end{array}$ & & \\
\hline & & & $\begin{array}{c}\text { Width: } \\
9.1 / 9 \text { vs } 7.9 / 7.7\end{array}$ & & \\
\hline
\end{tabular}

Table 6. Study's that reported clinical analysis

\begin{tabular}{|c|c|c|c|c|c|}
\hline References & $\begin{array}{l}\text { Extraction } \\
\text { location }\end{array}$ & Preservation method & $\begin{array}{c}\text { Difference } \\
\text { (experimental vs control, } \mathrm{mm} \text { ) }\end{array}$ & $\begin{array}{l}\text { Control } \\
\text { group }\end{array}$ & $\begin{array}{c}\text { Period } \\
\text { observation }\end{array}$ \\
\hline \multirow{3}{*}{ Lekovic et al. [12] } & \multirow{3}{*}{$\begin{array}{c}\text { Anterior and } \\
\text { premolar teeth }\end{array}$} & Control group: blood clot & $\begin{array}{l}\text { External vertical measurement: } \\
3.19 / 2.81 \text { vs } 3.31 / 1.81\end{array}$ & \multirow{3}{*}{16} & \multirow{3}{*}{6 months } \\
\hline & & \multirow{2}{*}{$\begin{array}{c}\text { Test group: sockets grafted with } \\
\text { bovine bone mineral and covered with } \\
\text { bioabsorbable membrane made of glycolide } \\
\text { and lactide polymers }\end{array}$} & $\begin{array}{l}\text { Internal vertical measurement: } \\
6.88 / 1.06 \text { vs } 6.94 / 3\end{array}$ & & \\
\hline & & & $\begin{array}{c}\text { Horizontal measurement: } \\
7.38 / 6.06 \text { vs } 7.5 / 2.94\end{array}$ & & \\
\hline
\end{tabular}


Table 7. Study's that reported histological and histomorphometric analysis

\begin{tabular}{|c|c|c|c|c|c|}
\hline References & $\begin{array}{c}\% \\
\text { (vital bone) }\end{array}$ & \begin{tabular}{|c|}
$\%$ \\
(residual graft)
\end{tabular} & $\begin{array}{c}\text { \% bone volume } \\
\text { (vital bone + residual graft) }\end{array}$ & $\begin{array}{c}\% \\
\text { (connective tissue) }\end{array}$ & Significance \\
\hline Iasella et al. [21] & $\begin{array}{l}\text { Group RP: } \\
28 \text { (SD 14); } \\
\text { Group EXT: } \\
54 \text { (SD 12) }\end{array}$ & $\begin{array}{c}\text { Group RP: } \\
37 \text { (SD 18); } \\
\text { Group EXT: } \\
\text { no data }\end{array}$ & $\begin{array}{r}\text { Group RP: } \\
65 \text { (SD 10); } \\
\text { Group EXT: } \\
54 \text { (SD 12) } \\
\end{array}$ & No data & $\mathrm{P}<0.05$ \\
\hline Perelman-Karmon et al. [46] & $\begin{array}{c}\text { Group A: } \\
\text { Bio-Oss }^{\circledR} \\
29.7\left(\text { SD }^{\circledR} .21\right) \% \\
\text { Group B: }^{\text {B }} \\
\text { Bio-Oss }^{\circledR}+\text { Bio-Guide } \\
\text { 40.8 }(\text { SD } 10.61) \%\end{array}$ & No data & No data & No data & $\mathrm{P}<0.05$ \\
\hline Nam et al. [47] & $10.4(4.6)$ & 18,7 (SD 7) & 20.4 (SD 7.5) & $70.8(\mathrm{SD} 8,7)$ & $\mathrm{P}<0.05$ \\
\hline Barone et al. [48] & $\begin{array}{l}\text { Group RP: } \\
35.5 \text { (SD 10.4); } \\
\text { Group EXT: } \\
25.7 \text { (SD 9.5) }\end{array}$ & $\begin{array}{l}\text { Group RP: } \\
29.2 \text { (SD 10.1); } \\
\text { Group EXT: } \\
\text { no data }\end{array}$ & No data & $\begin{array}{l}\text { Group RP: } \\
\text { 36.6 (SD 12.6); } \\
\text { Group EXT: } \\
\text { 59.1 (SD 10.4) }\end{array}$ & $\mathrm{P}<0.05$ \\
\hline
\end{tabular}

$\mathrm{EXT}=$ extraction alone; $\mathrm{RP}=$ ridge preservation.

Iasella et al. [21] and Barone et al. [48], used a collagen membrane in their test groups comparing to the control group which was for both the extraction alone. In the Iasella et al. [21] study, the filling material was a mineralized freeze-dried bone allograft and in the Barone et al. [48] study, a corticocancellous porcine bone.

After an observation period of 6 months, Iasella et al. [21] concluded that ridge preservation using FDBA and a collagen membrane presented better results in terms of ridge height and width dimensions when compared to extraction alone. In the study of Barone et al. [48], after 7 to 9 months of healing period it was concluded that the ridge-preservation approach using porcine bone in combination with collagen membrane significantly limited the resorption of hard tissue ridge after tooth extraction compared to extraction alone.

Similar outcomes were found in a study of Meloni et al. [45], where after 17 months of the observation period, when two groups were compared, which have been grafting the sockets with deproteinized bovine bone sealed with epithelial connective tissue graft or a porcine collagen matrix. The authors concluded that the use of porcine collagen matrix allowed simplification of treatment because no palatal donor site was involved.

When a CBCT analysis was used comparing different types of treatment for the alveolar preservation, all results are better, independently of the material used, when compared to extraction socket alone. Anyhow there was a great variability of dimension changes between all of the studies analysed.

\section{Periapical X-ray analysis}

Data of Table 5 included only study of Nam et al. [47] and evaluated the results after $6-8$ months. Authors used different protocols, with the same purpose, to evaluate the dimensional changes in the alveolar ridge after tooth extraction.

Nam et al. [47], compared Group A - bovine bone mineral (BBM), OSC-B (Nano -Intelligent Bioengineering, Seoul, Korea) vs Group B - synthetic oligopeptide - Ossegen-X15 ${ }^{\circledR}$ (Nano Intelligent) and collagen membrane - Bio-Gide ${ }^{\circledR}$ (Geistlich Pharma $^{\circledR}$, Wolhusen, Switzerland). The ridge preservation was made in 42 patients, and they concluded that the ridgepreservation approach using synthetic oligopeptide coated bone mineral with collagen membrane effectively prevented the resorption of hard tissue with higher bone-to-graft contact, and the oligopeptidecoated bone may be a choice for ridge-preservation procedures while assuring new bone formation.

With limited information in the periapical X-ray analysis, it seems that the use of an alveolar preservation technique reduced the bone changes after tooth extraction.

\section{Clinical analysis}

Table 6 presents the data of Lekovic et al. [12] study, which evaluate the clinical effectiveness of the bioabsorbable membrane made of glycolide and lactide polymers in preserving alveolar ridges following tooth extraction.

Sixteen patients requiring extractions of two anterior teeth or bicuspids participated in the study (splitmouth design). Following the elevation of buccal and lingual full-thickness flaps and extraction of teeth, experimental sites were covered with bioabsorbable membranes; control sites did not receive any membrane. 
Flaps were advanced in order to achieve primary closure of the surgical wound.

Three different alveolar bone volume parameters were chosen: external vertical measurement and internal vertical measurements to rate the vertical changes of the post extraction socket and horizontal measurement. The results showed that the higher external vertical volume change from the baseline to the 6 months follow-up was found in the control group (-0.38 [SD 0.22] vs -1.5 [SD 0.26]). However, the internal vertical $(-5.81$ [SD 0.29] vs -3.94 [SD 0.35 ] and horizontal measurements (-1.31 [SD 0.24] vs -4.56 [SD 0.33]) presented with significantly less loss of alveolar bone height, more internal socket bone fill, and less horizontal reabsorption of the alveolar bone ridge during the follow-up in the control group.

Like in the previous studies, clinical analysis revealed that the alveolar preservation technique could be an advantage in reducing the alveolar bone dimensions after tooth extraction.

\section{Histological and histomorphometric analysis}

From the six papers included in Table 7, four trials $[21,46-48]$ reported information about the histological variables: percentage of vital bone (four studies $[\underline{21}, \underline{46-48}])$; percentage of residual graft (three studies $[\underline{21}, \underline{47}, \underline{48}]$ ), percentage of bone volume (two studies $[\underline{21}, \underline{47}]$ ), and percentage of connective tissue (two studies $[47,48])$.

Barone et al. in 2008 [48] presented the histologic analysis showing a significantly higher percentage of trabecular bone and total mineralized tissue in ridgepreservation sites compared to extraction-alone sites 7 months after tooth removal.

Nam et al. [47], presented the results of the histomorphometric analysis: percentage of residual graft, percentage of new bone, percentage of connective tissue and contact between particle and percentage of new bone, comparing the two groups. Results of these two trials $[\underline{47}, \underline{48}]$ confirmed advantage of the preservation technique comparing to the control.

In 2012, Perelman-Karmon et al. [46], compared extraction sites augmented with BBM with and without resorbable membrane coverage. BBM particles were grafted in fresh human extraction sockets of 23 patients; in 12 of these patients, a guided tissue regeneration method with collagen membrane was applied. After 9 months cylindric hard tissue sample were obtained for histomorphometric evaluation. Percent bone area fractions of the crestal, middle and apical sections from each sample were calculated using the point-counting technique. Changes in values were compared. In sites augmented with $\mathrm{BBM}$, the mean BAF ranged from $22.8 \%$ (coronal) to $36.3 \%$ (apical) compared to sites augmented with BBM and collagen membrane (35.2\% [coronal] to $47 \%$ [apical]). Comparison between the different depths and the two groups showed a distinct increase in BAF from coronal to apical regions $(\mathrm{P}<$ $0.001)$. This pattern was observed in both groups ( $\mathrm{P}$ $<0.001)$ and was significantly higher in the group augmented with BBM and collagen membrane (P $<0.05)$. In the immediate post extraction phase, BBM as a grafted biomaterial preserved the socket volume and enabled newly formed bone for future implant site preparation. The amount of the osseous fraction increased with collagen membrane.

In a study of Iasella et al. [21], the quantity of bone observed on histomorphometric analysis was slightly greater (statistically significant difference) in preservation sites, although these sites included both vital and non-vital bone but when analysed only the amount of vital bone this parameter was higher in control group. The most predictable maintenance of ridge width, height, and the position was achieved when a ridge preservation procedure was employed.

The two other authors $[\underline{46}, \underline{48}]$ showed that vital bone was higher in sockets that were preserved with a membrane. However, in one study [48] the natural healing was chosen as a control group and in the other [46] the grafting with a bovine bone. Therefore, even though the statistically significant differences were achieved in various studies, the results are heterogenic between the studies.

The results presented for the different papers must be analysed with caution because they used different materials in the preservation techniques and different time of analysis. They also included different types of defects, so it is impossible to compare the results between the different studies.

\section{DISCUSSION}

This systematic review was focused on evaluating the effect of different alveolar preservation techniques performed immediately after tooth extraction, in particular, to assess quantitatively and qualitatively the influence of two different factors (membranes and soft tissue graft).

The research questions of this systematic review were "Are there radiological, histological, histomorphometric or clinical differences in humans extraction socket preservation when we are performed 
with and without membranes with a follow-up of at least 6 months" and "Are there radiological, histological, histomorphometric or clinical differences in humans extraction socket preservation when a soft tissue graft is performed with a follow-up of at least 6 months"

For this purpose, it was made a wide-ranging electronic search for all related articles up to 30 of November 2018 in the following electronic databases: LILACS, PubMed, SciELO, ScienceDirect, Scopus and Web of Science, with no data restriction.

Based on a clinical purpose, the included papers were only clinical trials and randomized clinical trials, using keywords combinations already presented. It was also made an additional manual search among periodical journals and grey literature of relevant papers.

No animal studies were included. Only intact sockets were included following the same definition propose by Hämmerle et al. [49] "ridge preservation $=$ preserving the ridge volume within the envelope existing at the time of extraction". The included studies should have at least 12 patients or treated 12 sites per group and when the studies tried to analyse the membrane effect a control group without membrane need to be present.

Based on the inclusion and exclusion criteria there was a lack of information, as reported previously, to take strength conclusions.

There was a great variability of the techniques and materials used, analysed variables, location of the extraction sites and also the time of evaluation.

\section{Treatment combinations}

A. Control group (blood clot) vs test group (collagen membrane + filling material): two studies (Iasella et al. [21] and Barone et al. [48]).

B. Control group (blood clot) vs test group (BBM + bioabsorbable membrane made of glycolide and lactide polymers): one study (Lekovic et al. [12]).

C. Control group (deproteinized bovine bone + epithelial connective tissue graft) vs test group (deproteinized bovine bone + collagen matrix): one study (Meloni et al. [다]).

D. Control group $\left(\right.$ Bio-Oss $^{\circledR}\left[\right.$ Geistlich Pharma ${ }^{\circledR}$, Wolhusen, Swiss]) vs test group (Bio-Oss ${ }^{\circledR}+$ collagen membrane): one study (PerelmanKarmon et al. [46]).

E. Control group (deproteinized bovine bone) vs test group (collagen membrane) - one study (Nam et al. [느]).

\section{Analysed variables}

From the six included studies, three evaluated the results based on the CBCT analysis $[21,45, \underline{48}]$, one on the periapical X-ray [47], one on the clinical variables [12] and four on the histological and histomorphometric analysis $[\underline{21}, \underline{46-48]}$.

\section{Extraction sites}

Most of the papers referred that the tooth extractions were made in the anterior zone of the maxilla, but in some of them, there was a lack of information $[\underline{45}, \underline{48}]$.

\section{Time of evaluation}

Most of the papers evaluate the results at 6 months after tooth extraction, but there are some that the evaluation period was later, at 9 and 17 months [45]. The risk of bias was high in four of six papers, and it was low in two of them.

As one of the focus questions was related to the advantage or not by using a membrane in alveolar preservation techniques, there were only two studies that compare the use of membrane against blood clot (Iasella et al. [21] and Barone et al. [48]) which presented better results for the test (membrane) group. Both studies made a CBCT and histomorphometric analysis.

There was another study (Perelman-Karmon et al. [46]) which compare the use of BBM $\left(\mathrm{Bio-Oss}^{\circledR}\right)$ in the control group versus BBM (Bio-Oss ${ }^{\circledR}$ ) and collagen membrane in the test group. They made a histological and histomorphometric analysis and confirm the advantages of the use of a membrane. The conclusion was that the BBM, as a grafted biomaterial in fresh extraction sockets, preserved its volume and enabled newly formed bone for future implant site preparation and the application of collagen membrane increased the osseous fraction.

The other focus question was about the advantage of using the soft tissue graft. For this particular question, there was one selected study by Meloni et al. [45] using CBCT analysis as control method. Meloni et al. [45] reported that sealing the socket with a porcine collagen matrix or epithelial connective tissue graft showed similar outcomes if added to the BBM. Anyhow this study does not compare the use of soft tissue graft with control group, which means that this particular conclusion enables to confirm the advantage of using the soft tissue in the alveolar preservation techniques.

All of the other studies could give us an idea about the possible advantages of using the membrane, but they cannot clearly confirm and support this conclusion. 


\section{CONCLUSIONS}

1. Based on cone-beam computed tomography, periapical X-ray, clinical and histological and histomorphometric findings it can be concluded that the alveolar preservation techniques, presented in this systematic review, can decrease the dimensional reduction of the alveolar ridge that usually occurs after tooth extraction as compared to tooth extraction alone.

2. After analysis of the selected studies it is impossible to recommend any specific techniques and/or materials to achieve improved results of extraction socket preservation because of the lack of sufficient data.
3. Few studies that compare the use of the alveolar preservation techniques with and without membrane, demonstrated that the application of the membrane allows to achieve superior preservation results.

4. There is lack of information concerning the advantage of soft tissue graft using in the alveolar preservation techniques.

\section{ACKNOWLEDGMENTS AND DISCLOSURE STATEMENTS}

The authors report no conflicts of interest related to this study.

\section{REFERENCES}

1. Chapple IL, Wilson NH. Manifesto for a paradigm shift: periodontal health for a better life. Br Dent J. 2014 Feb;216(4): 159-62. [Medline: 24557384] [doi: $10.1038 /$ sj.bdj.2014.97]

2. Ali Z, Baker SR, Shahrbaf S, Martin N, Vettore MV. Oral health-related quality of life after prosthodontic treatment for patients with partial edentulism: A systematic review and meta-analysis. J Prosthet Dent. 2019 Jan;121(1):59-68.e3. [Medline: 30006220 ] [doi: 10.1016/j.prosdent.2018.03.003]

3. Wolleb K, Sailer I, Thoma A, Menghini G, Hammerle CH. Clinical and radiographic evaluation of patients receiving both tooth- and implant-supported prosthodontic treatment after 5 years of function. Int J Prosthodont. 2012 MayJun;25(3):252-9. [Medline: 22545254]

4. Chappuis V, Engel O, Reyes M, Shahim K, Nolte LP, Buser D. Ridge alterations post-extraction in the esthetic zone: a 3D analysis with CBCT. J Dent Res. 2013 Dec;92(12 Suppl):195S-201S. [Medline: 24158340] [PMC free article: 3860068 ] [doi: 10.1177/0022034513506713]

5. Chappuis V, Engel O, Shahim K, Reyes M, Katsaros C, Buser D. Soft Tissue Alterations in Esthetic Postextraction Sites: A 3-Dimensional Analysis. J Dent Res. 2015 Sep;94(9 Suppl):187S-93S. [Medline: 26130259] [doi: $10.1177 / 0022034515592869]$

6. Araújo MG, Lindhe J. Dimensional ridge alterations following tooth extraction. An experimental study in the dog. J Clin Periodontol. 2005 Feb;32(2):212-8. [Medline: 15691354] [doi: 10.1111/j.1600-051X.2005.00642.x]

7. Trombelli L, Farina R, Marzola A, Bozzi L, Liljenberg B, Lindhe J. Modeling and remodeling of human extraction sockets. J Clin Periodontol. 2008 Jul;35(7):630-9. [Medline: 18498382] [doi: 10.1111/j.1600-051X.2008.01246.x]

8. Discepoli N, Vignoletti F, Laino L, de Sanctis M, Muñoz F, Sanz M. Early healing of the alveolar process after tooth extraction: an experimental study in the beagle dog. J Clin Periodontol. 2013 Jun;40(6):638-44. [Medline: 23534915] [doi: $10.1111 /$ jcpe. 12074$]$

9. Tan WL, Wong TL, Wong MC, Lang NP. A systematic review of post-extractional alveolar hard and soft tissue dimensional changes in humans. Clin Oral Implants Res. 2012 Feb;23 Suppl 5:1-21. [Medline: 22211303] [doi: 10.1111/j.1600-0501.2011.02375.x]

10. Van der Weijden F, Dell'Acqua F, Slot DE. Alveolar bone dimensional changes of post-extraction sockets in humans: a systematic review. J Clin Periodontol. 2009 Dec;36(12):1048-58. [Medline: 19929956] [doi: 10.1111/j.1600051X.2009.01482.X]

11. Willenbacher M, Al-Nawas B, Berres M, Kämmerer PW, Schiegnitz E. The Effects of Alveolar Ridge Preservation: A Meta-Analysis. Clin Implant Dent Relat Res. 2016 Dec;18(6):1248-1268. [Medline: 26132885] [doi: 10.1111/cid.12364]

12. Lekovic V, Camargo PM, Klokkevold PR, Weinlaender M, Kenney EB, Dimitrijevic B, Nedic M. Preservation of alveolar bone in extraction sockets using bioabsorbable membranes. J Periodontol. 1998 Sep;69(9):1044-9. [Medline: 9776033] [doi: 10.1902/jop.1998.69.9.1044]

13. Clementini M, Tiravia L, De Risi V, Vittorini Orgeas G, Mannocci A, de Sanctis M. Dimensional changes after immediate implant placement with or without simultaneous regenerative procedures: a systematic review and meta-analysis. J Clin Periodontol. 2015 Jul;42(7):666-77. [Medline: 26073267] [doi: 10.1111/jepe.12423]

14. Lang NP, Pun L, Lau KY, Li KY, Wong MC. A systematic review on survival and success rates of implants placed immediately into fresh extraction sockets after at least 1 year. Clin Oral Implants Res. 2012 Feb;23 Suppl 5:39-66. [Medline: 22211305] [doi: 10.1111/j.1600-0501.2011.02372.x] 
15. Álvarez-Camino JC, Valmaseda-Castellón E, Gay-Escoda C. Immediate implants placed in fresh sockets associated to periapical infectious processes. A systematic review. Med Oral Patol Oral Cir Bucal. 2013 Sep 1;18(5):e780-5. [Medline: 23722139] [PMC free article: 3790652] [doi: 10.4317/medoral.18942]

16. Bäumer D, Zuhr O, Rebele S, Hürzeler M. Socket Shield Technique for immediate implant placement - clinical, radiographic and volumetric data after 5 years. Clin Oral Implants Res. 2017 Nov;28(11):1450-1458. [Medline: 28333394] [doi: 10.1111/clr.13012]

17. Hürzeler MB, Zuhr O, Schupbach P, Rebele SF, Emmanouilidis N, Fickl S. The socket-shield technique: a proof-of-principle report. J Clin Periodontol. 2010 Sep;37(9):855-62. [Medline: 20712701] [doi: 10.1111/j.1600-051X.2010.01595.x]

18. Salama M, Ishikawa T, Salama H, Funato A, Garber D. Advantages of the root submergence technique for pontic site development in esthetic implant therapy. Int J Periodontics Restorative Dent. 2007 Dec;27(6):521-7. [Medline: 18092446] [doi: 10.11607/prd.00.0775]

19. Artzi Z, Tal H, Dayan D. Porous bovine bone mineral in healing of human extraction sockets. Part 1: histomorphometric evaluations at 9 months. J Periodontol. 2000 Jun;71(6):1015-23. [Medline: 10914806] [doi: 10.1902/jop.2000.71.6.1015]

20. Brugnami F, Caiazzo A. Efficacy evaluation of a new buccal bone plate preservation technique: a pilot study. Int J Periodontics Restorative Dent. 2011 Feb;31(1):67-73. [Medline: 21365028]

21. Iasella JM, Greenwell H, Miller RL, Hill M, Drisko C, Bohra AA, Scheetz JP. Ridge preservation with freeze-dried bone allograft and a collagen membrane compared to extraction alone for implant site development: a clinical and histologic study in humans. J Periodontol. 2003 Jul;74(7):990-9. [Medline: 12931761] [doi: 10.1902/jop.2003.74.7.990]

22. Avila-Ortiz G, Elangovan S, Kramer KW, Blanchette D, Dawson DV. Effect of alveolar ridge preservation after tooth extraction: a systematic review and meta-analysis. J Dent Res. 2014 Oct;93(10):950-8. [Medline: 24966231] [PMC free article: 4293706] [doi: 10.1177/0022034514541127]

23. Iocca O, Farcomeni A, Pardiñas Lopez S, Talib HS. Alveolar ridge preservation after tooth extraction: a Bayesian Network meta-analysis of grafting materials efficacy on prevention of bone height and width reduction. J Clin Periodontol. 2017 Jan;44(1):104-114. [Medline: 27712001] [doi: 10.1111/jepe.12633]

24. MacBeth N, Trullenque-Eriksson A, Donos N, Mardas N. Hard and soft tissue changes following alveolar ridge preservation: a systematic review. Clin Oral Implants Res. 2017 Aug;28(8):982-1004. [Medline: 27458031] [doi: $10.1111 /$ clr.12911]

25. Vignoletti F, Matesanz P, Rodrigo D, Figuero E, Martin C, Sanz M. Surgical protocols for ridge preservation after tooth extraction. A systematic review. Clin Oral Implants Res. 2012 Feb;23 Suppl 5:22-38. [Medline: 22211304] [doi: 10.1111/j.1600-0501.2011.02331.x]

26. Vittorini Orgeas G, Clementini M, De Risi V, de Sanctis M. Surgical techniques for alveolar socket preservation: a systematic review. Int J Oral Maxillofac Implants. 2013 Jul-Aug;28(4):1049-61. [Medline: 23869363] [doi: 10.11607/jomi.2670]

27. Becker W, Becker BE, Caffesse R. A comparison of demineralized freeze-dried bone and autologous bone to induce bone formation in human extraction sockets. J Periodontol. 1994 Dec;65(12):1128-33. Erratum in: J Periodontol 1995 Apr;66(4):309. Erratum in: J Periodontol. 1995 Apr;66(4):309. [Medline: 7877084] [doi: 10.1902/jop.1994.65.12.1128]

28. Froum S, Cho SC, Rosenberg E, Rohrer M, Tarnow D. Histological comparison of healing extraction sockets implanted with bioactive glass or demineralized freeze-dried bone allograft: a pilot study. J Periodontol. 2002 Jan;73(1):94-102. [Medline: 11846205] [doi: 10.1902/jop.2002.73.1.94]

29. Serino G, Biancu S, Iezzi G, Piattelli A. Ridge preservation following tooth extraction using a polylactide and polyglycolide sponge as space filler: a clinical and histological study in humans. Clin Oral Implants Res. 2003 Oct;14(5):651-8. [Medline: 12969370] [doi: 10.1034/j.1600-0501.2003.00970.x]

30. Heberer S, Al-Chawaf B, Hildebrand D, Nelson JJ, Nelson K. Histomorphometric analysis of extraction sockets augmented with Bio-Oss Collagen after a 6-week healing period: a prospective study. Clin Oral Implants Res. 2008 Dec;19(12):1219-25. [Medline: 19040436] [doi: 10.1111/j.1600-0501.2008.01617.x]

31. Higgins JP, Green S. Cochrane Handbook for Systematic Reviews of Interventions. C.B. Series. England: Wiley and Backwell. 2008. [doi: 10.1002/9780470712184]

32. Liberati A, Altman DG, Tetzlaff J, Mulrow C, Gøtzsche PC, Ioannidis JP, Clarke M, Devereaux PJ, Kleijnen J, Moher D. The PRISMA statement for reporting systematic reviews and meta-analyses of studies that evaluate healthcare interventions: explanation and elaboration. BMJ. 2009 Jul 21;339:b2700. [Medline: 19622552] [PMC free article: 2714672] [doi: 10.1136/bmj.b2700]

33. Festa VM, Addabbo F, Laino L, Femiano F, Rullo R. Porcine-derived xenograft combined with a soft cortical membrane versus extraction alone for implant site development: a clinical study in humans. Clin Implant Dent Relat Res. 2013 Oct;15(5):707-13. [Medline: 22082037] [doi: 10.1111/j.1708-8208.2011.00398.x]

34. Jonker BP, Wolvius EB, van der Tas JT, Pijpe J. The effect of resorbable membranes on one-stage ridge augmentation in anterior single-tooth replacement: A randomized, controlled clinical trial. Clin Oral Implants Res. 2018 Feb;29(2): 235-247. [Medline: 29266485] [doi: 10.1111/clr.13106]

35. Aimetti M, Manavella V, Corano L, Ercoli E, Bignardi C, Romano F. Three-dimensional analysis of bone remodeling following ridge augmentation of compromised extraction sockets in periodontitis patients: A randomized controlled study. Clin Oral Implants Res. 2018 Feb;29(2):202-214. [Medline: 29148597] [doi: 10.1111/clr.13099] 
36. Scheyer ET, Heard R, Janakievski J, Mandelaris G, Nevins ML, Pickering SR, Richardson CR, Pope B, Toback G, Velásquez D, Nagursky H. A randomized, controlled, multicentre clinical trial of post-extraction alveolar ridge preservation. J Clin Periodontol. 2016 Dec;43(12):1188-1199. [Medline: 27617409] [PMC free article: 5132058] [doi: 10.1111/jcpe.12623]

37. Carmagnola D, Adriaens P, Berglundh T. Healing of human extraction sockets filled with Bio-Oss. Clin Oral Implants Res. 2003 Apr;14(2):137-43. [Medline: 12656871] [doi: 10.1034/j.1600-0501.2003.140201.x]

38. Brkovic BM, Prasad HS, Rohrer MD, Konandreas G, Agrogiannis G, Antunovic D, Sándor GK. Beta-tricalcium phosphate/type I collagen cones with or without a barrier membrane in human extraction socket healing: clinical, histologic, histomorphometric, and immunohistochemical evaluation. Clin Oral Investig. 2012 Apr;16(2):581-90. [Medline: 21369794] [doi: 10.1007/s00784-011-0531-1]

39. Fickl S, Fischer K, Petersen N, Happe A, Schlee M, Schlagenhauf U, Kebschull M. Dimensional Evaluation of Different Ridge Preservation Techniques: A Randomized Clinical Study. Int J Periodontics Restorative Dent. 2017 May/Jun;37(3):403-410. [Medline: 28402351] [doi: 10.11607/prd.2629]

40. Leblebicioglu B, Salas M, Ort Y, Johnson A, Yildiz VO, Kim DG, Agarwal S, Tatakis DN. Determinants of alveolar ridge preservation differ by anatomic location. J Clin Periodontol. 2013 Apr;40(4):387-95. [Medline: 23432761] [PMC free article: 4955554] [doi: 10.1111/jepe.12065]

41. Cardaropoli D, Tamagnone L, Roffredo A, Gaveglio L. Evaluation of Dental Implants Placed in Preserved and Nonpreserved Postextraction Ridges: A 12-Month Postloading Study. Int J Periodontics Restorative Dent. 2015 Sep-Oct;35(5):677-85. [Medline: 26357697] [doi: 10.11607/prd.2309]

42. Barone A, Toti P, Piattelli A, Iezzi G, Derchi G, Covani U. Extraction socket healing in humans after ridge preservation techniques: comparison between flapless and flapped procedures in a randomized clinical trial. J Periodontol. 2014 Jan;85(1):14-23. [Medline: 23688103] [doi: 10.1902/jop.2013.120711]

43. De Santis D, Cucchi A, de Gemmis A, Nocini Pier F. New collagen matrix to avoid the reduction of keratinized tissue during guided bone regeneration in postextraction sites. J Craniofac Surg. 2012 May;23(3):e186-9. [Medline: 22627428] [doi: 10.1097/SCS.0b013e31824de62c]

44. Filipek D, Koszowski R, Smieszek-Wilczewska J. A comparative clinical study on human tooth extractions: flap vs flapless buccal surgery. Quintessence Int. 2012 Nov-Dec;43(10):887-9. [Medline: 23115768]

45. Meloni SM, Tallarico M, Lolli FM, Deledda A, Pisano M, Jovanovic SA. Postextraction socket preservation using epithelial connective tissue graft vs porcine collagen matrix. 1-year results of a randomised controlled trial. Eur J Oral Implantol. 2015 Spring;8(1):39-48. [Medline: 25738178]

46. Perelman-Karmon. M, et al., Socket site preservation using bovine bone mineral with and without a bioresorbable collagen membrane. Int J Periodontics Restorative Dent, 2012. 32(4): p. 459-65. [Medline: 22577652] [doi: 10.11607/prd.00.1087]

47. Nam HW, Park JB, Lee JY, Rhee SH, Lee SC, Koo KT, Kim TI, Seol YJ, Lee YM, Ku Y, Rhyu IC, Park YJ, Chung CP. Enhanced ridge preservation by bone mineral bound with collagen-binding synthetic oligopeptide: a clinical and histologic study in humans. J Periodontol. 2011 Mar;82(3):471-80. [Medline: 20932159] [doi: 10.1902/jop.2010.100193]

48. Barone A, Aldini NN, Fini M, Giardino R, Calvo Guirado JL, Covani U. Xenograft versus extraction alone for ridge preservation after tooth removal: a clinical and histomorphometric study. J Periodontol. 2008 Aug;79(8):1370-7. [Medline: 18672985] [doi: 10.1902/jop.2008.070628]

49. Hämmerle $\mathrm{CH}$, Araújo $\mathrm{MG}$, Simion M; Osteology Consensus Group 2011. Evidence-based knowledge on the biology and treatment of extraction sockets. Clin Oral Implants Res. 2012 Feb;23 Suppl 5:80-2. [Medline: 22211307] [doi: $10.1111 / \mathrm{j} .1600-0501.2011 .02370 . \mathrm{x}$ ]

\section{To cite this article:}

Faria-Almeida R, Astramskaite-Januseviciene I, Puisys A, Correia F.

Extraction Socket Preservation with or without Membranes, Soft Tissue Influence on Post Extraction Alveolar Ridge Preservation: a Systematic Review

J Oral Maxillofac Res 2019;10(3):e5

URL: http://www.ejomr.org/JOMR/archives/2019/3/e5/v10n3e5.pdf

doi: $10.5037 /$ jomr.2019.10305

Copyright (C) Faria-Almeida R, Astramskaite-Januseviciene I, Puisys A, Correia F. Published in the JOURNAL OF ORAL \& MAXILLOFACIAL RESEARCH (http://www.ejomr.org), 5 September 2019.

This is an open-access article, first published in the JOURNAL OF ORAL \& MAXILLOFACIAL RESEARCH, distributed under the terms of the Creative Commons Attribution-Noncommercial-No Derivative Works 3.0 Unported License, which permits unrestricted non-commercial use, distribution, and reproduction in any medium, provided the original work and is properly cited. The copyright, license information and link to the original publication on (http://www.ejomr.org) must be included. 